\title{
Pengaruh Social Media Marketing, Brand Awareness Terhadap Keputusan Pembelian Dengan Minat Beli Sebagai Variabel Intervening Pada J.Co Donuts \& Coffee Semarang
}

\author{
Meatry Kurniasari ${ }^{1, *}$, Agung Budiatmo ${ }^{2}$ \\ Departemen Administrasi Bisnis, Fakulitas Ilmu Sosial dan Ilmu Politik, Universitas Diponegoro \\ Email: meatrikurnia@gmail.com
}

\begin{abstract}
The purpose of this study is to determine the influence of social media marketing and brand awarenessof purchasing decisions through buying interest as an intervening variable J.CO Donuts \& Coffee in Semarang City. This type of research is explanatory research. Sampling technique using non probability sampling technique with purposive sampling and Accidental sampling method. The number of samples taken as many as 100 respondents with a ratio of 40:60 in both branches J.CO Donuts \& Coffee Semarang. In this study assisted by SPSS 16.0 system. The results showed that social media marketing influence on buying interest by contributing $15.6 \%$ while the rest influenced by factors other than social media marketing. Brand Awareness influences buying interest by contributing $31.3 \%$ while the rest is influenced by factors other than brand awareness. Meanwhile, buying interest influences the purchasing decision by contributing $23.3 \%$ while the rest is influenced by factors other than buying interest. Based on result of regression analysis of two stages known that variable of buying interest can be intervening variable from social media marketing and brand awareness to purchasing decision. It means that the better social media marketing and brand awareness, the higher the buying interest and the better the buying interest, the higher the purchasing decision of J.CO Donuts \& Coffee in Semarang City.
\end{abstract}

\begin{abstract}
Abstraksi Tujuan penelitian ini adalah untuk mengetahui pengaruh social media marketing dan brand awareness terhadap keputusan pembelian melalui minat beli sebagai variabel intervening J.CO Donuts \& Coffee di Kota Semarang. Tipe penelitian ini adalah explanatory research. Teknik pengambilan sampel menggunakan teknik nonprobability sampling dengan metode Purposive sampling dan Accidental sampling. Adapun jumlah sampel yang diambil sebanyak 100 responden dengan perbandingan 40:60 di kedua cabang J.CO Donuts \& Coffee Semarang. Dalam penelitian ini dibantu oleh sistem SPSS 16.0. Hasil penelitian menunjukan bahwa social media marketing berpengaruh terhadap minat beli dengan menyumbang 15,6\% sedangkan sisanya dipengaruhi oleh faktor selain social media marketing. Brand Awareness berpengaruh terhadap minat beli dengan menyumbang 31,3\% sedangkan sisanya dipengaruhi oleh faktor selain brand awareness. Sedangkan, minat beli berpengaruh terhadap keputusan pembelian dengan menyumbang $23,3 \%$ sedangkan sisanya dipengaruhi oleh faktor selain minat beli. Berdasarkan hasil analisis regresi dua tahap diketahui bahwa variabel minat beli dapat menjadi variabel intervening dari social media marketing dan brand awareness terhadap keputusan pembelian. Artinya semakin baik social media marketing dan brand awareness maka semakin tinggi minat beli dan semakin baik minat beli maka juga semakin tinggi pula keputusan pembelian J.CO Donuts \& Coffee di Kota Semarang.
\end{abstract}

Keywords: Brand Image; Brand Trust; Purchasing Decision; Word Of Mouth

\section{Pendahuluan}

Peluang pasar di era globalisasi ini sangat besar, maka marketer harus cerdas serta memiliki kepekaan dalam mencermati setiap hal yang ada dalam pasar konsumen. Keunggulan kompetitif hanya dapat dimiliki perusahaan, jika pihak pemasar dapat menjadikan harapan konsumen menjadi kenyataan. Selera dan tuntutan konsumen yang terus menerus mengalami peningkatan harus dapat dijadikan feedback yang nantinya dapat meningkatkan market share perusahaan. Perusahaan terutama pada segmen bisnis retail yang tidak dapat mengikuti trend marketing dan trend konsumen di pasar akan tergeser. Perusahaan harus memiliki keunikan yang menjadikannya lebih dari kompetitor dan memiliki nilai daya tarik tersendiri bagi konsumen melalui etalase toko, varian produk, merek perusahaan, maupun melalui strategi promosi dalam menjaring konsumen.

Salah satu bisnis retail yang menjadi fenomena dalam masyarakat modern sekarang ini adalah bisnis retail cafe modern. Berbagai cafe modern menjadi 
sorotan utama bagi masyarakat, terutama segmen kalangan muda. Masyarakat Indonesia, khususnya kalangan muda dan komunitas netizen di social media merupakan pasar potensial bagi bisnis retail cafe modern.Alasannya karena mereka merupakan pihak yang selalu meng-update trend life style di masyarakat.

Menurut Kotler dan Keller (2012), social media merupakan sarana bagi konsumen untuk berbagi informasi teks, gambar, audio dan video dengan satu sama lain dan dengan perusahaan dan sebaliknya. Sedangkan, social media marketing merupakan bentuk pemasaran yang dipakai untuk meciptakan kesadaran, pengakuan, ingatan dan bahkan tindakan terhadap suatu merk, produk, bisnis, individu, atau kelompok baik secara langsung maupun tidak langsung dengan menggunakan alat dari web sosial seperti blogging, microblogging, dan jejaring sosial (Setiawan, 2015).

Banyak perusahaan beranggapan bahwa mengaplikasikan social media marketing saja dapat memudahkan dan menambah value bagi produknya,lebih murah dan efisien. Dampaknya terhadap penjualan akan besar jika banyak konsumen dan pelanggan yang berkunjung ke situs tersebut dan mengetahui merk yang sedang ditawarkan. Salah satu tujuan dari pemasaran yang efektif adalah untuk mengenalkan keberadaan suatu produk tersebut menjadi top of mind dan menjadi pilihan dari konsumen untuk membeli produk yang ditawarkan.

Selain social media, Brand Awareness dapat mempengaruhi minat beli dari konsumen. Brand Awareness menurut Durianto (2004) mendefinisikan kesanggupan seorang calon pembeli untuk mengenali, mengingat kembali suatu merk sebagai bagian dari suatu kategori produk tertentu. Sedangkan menurut Menurut Tjiptono (2007) kesadaran merk adalah kesanggupan seseorang calon pembeli untuk mengenali atau mengingat kembali bahwa suatu merk merupakan bagian dari kategori produk tertentu.
Selama 3 tahun terakhir yaitu tahun 2014-2016 pada Top Brand Index J.CO Donuts \& Coffee menempati posisi semakin menurun tiap tahunnya bahkan pada tahun 2015 dan 2016 merek J.CO Donuts \& Coffee tidak termasuk pada kategori kafe kopi seperti di tahun 2014. J.CO Donuts \& Coffee memiliki keunggulan pada produk-produknya terutama produk donatnya yang banyak digemari oleh konsumen sampai saat ini dan J.CO Donuts \& Coffee masih mampu bertahan ditengah persaingan yang semakin ketat, namun dalam kurun waktu beberapa tahun terakhir volume penjualannya mengalami penurunan. Penurunan tingkat penjualan ini jelas akan mempengaruhi nilai keuntungan yang diperoleh perusahaan.

Volume penjualan produk pada J.CO Donuts \& Coffee mengalami fluktuasi dari tahun ke tahun dalam tiga tahun terakhir. Pada tahun 2014 penjualan produk J.CO Donuts \& Coffee sebesar Rp. 14.933.697.793 dalam setahun dan mengalami peningkatan di tahun 2015 sebesar 3,65\% menjadi Rp. 15.478.038.895. Di tahun 2016 penjualan produk J.CO Donuts \& Coffee mengalami penurunan $2,51 \%$ dengan penjualan produk J.CO Donuts \& Coffee sebesar Rp. 15.089.501.586.

Fluktuasi volume penjualan tersebut karena kondisi persaingan yang semakin ketat dengan promosi yang bersaing sehingga konsumen akan memilih mana yang palik menarik sehingga menimbulkan minat beli di benak mereka yang selanjutnya akan mempengaruhi keputusan pembelian. Rumusan masalah dalam penelitian ini yaitu: (1)Apakah terdapat pengaruh social media marketing terhadap minat beli J.CO Donuts \& Coffee di Kota Semarang? (2) Apakah terdapat pengaruh brand awareness terhadap minat beli J.CO Donuts \& Coffee J di Kota Semarang? (3) Apakah terdapat minat beli terhadap keputusan pembelian J.CO Donuts \& Coffee di Kota Semarang?

Tujuan penelitian ini yaitu: (1) Untuk mengetahui pengaruh social media marketing terhadap minat beli J.CO Donuts \& Coffee di Kota Semarang; (2)Untuk mengetahui 
pengaruh brand awareness terhadap minat beli J.CO Donuts \& Coffee di Kota Semarang; (3) Untuk mengetahui pengaruh minat beli terhadap keputusan pembelian J.CO Donuts \& Coffee di Kota Semarang.

\section{Kerangka Teori}

Menurut Kaplan dan Haenlein (2010), social media didefinisikan sebagai sebuah kelompok aplikasi berbasis internet yang dibangun atas dasar ideology dan teknologi Web 2.0.Web 2.0 adalah dasar platform media sosial. Media sosial sendiri terdiri dari bermacam-macam bentuk yang berbeda, seperti social network, forum internet, weblogs, social blogs, micro blogging, wikis, prodcasts, gambar, video, rating dan bookmark social. Menurut DeMers (2014) indicator yang digunakan untuk mengukur social media marketing antara lain: (1) Tulisan yang berkualitas; (2) Foto yang menarik; (3) Frekuensi keaktifan postingan.

Kesadaran merek (brand awareness) adalah kesanggupan seorang calon pembeli untuk mengenali, mengingat kembali suatu merek sebagai bagian dari suatu kategori produk tertentu. Menurut Durianto (2004) indikator yang digunakan untuk mengukur brand awareness antara lain: (1) Popularitas suatu merek; (2) Tingkat pengetahuan merek; (3) Merek menjadi pilihan utama.

Minat beli konsumen adalah tahap dimana konsumen membentuk pilihan mereka di antara beberapa merek yang tergabung dalam perangkat pilihan, kemudian pada akhirnya melakukan suatu pembelian pada suatu altenatif yang paling disukainya atau proses yang dilalui konsumen untuk membeli suatu barang atau jasa yang didasari oleh bermacam pertimbangan. Menurut Sukmawati dan Suyono dalam Pramono (2012) indicator yang digunakan untuk mengukur minat beli antara lain: (1) Ketertarikan terhadap produk; (2) Keinginan untuk membeli produk; (3) Memilih produk.

Keputusan pembelian adalah tahap proses keputusan dimana konsumen secara actual melakukan pembelian produk.
Sebelum transaksi dilakukan terdapat prosesproses yang terjadi dan senantiasa menyertai setiap pembelian yakni pertimbanganpertimbangan (Kotler, 2001). Indikator yang digunakan untuk mengukur keputusan pembelian antara lain: (1) Kemantapan Produk; (2) Merekomendasikan Produk; (3) Melakukan pembelian ulang.

\section{Metode}

Tipe penelitian yang digunakan dalam penelitian ini adalah tipe explanatory yaitu penelitian yang bermaksud menyoroti hubungan variabel-variabel penelitian kemudian menguji hipotesis yang telah dirumuskan sebelumnya. Penelitian ini korelasinya berfokus pada pengaruh antar variabel Social Media Marketing (X1), Brand Awareness (X2) terhadap variabel Keputusan Pembelian (Y) melalui Minat Beli (Z) sebagai variabel intervening.

Dalam penelitian ini, penulis menggunakan teknik Non-probability Sampling yaitu accidental sampling, yang mana dalam pengambilan sampel responden dapat ditemui secara acak ketika bertemu dengan peneliti tetapi dipilih responden mana yang memenuhi karakteristik dari peneliti. Selain accidental sampling, teknik purposive sampling juga digunakan pada penelitian ini, teknik purposive sampling adalah penentuan sampel berdasarkan pertimbangan tertentu, yaitu orang-orang tertentu yangcocok sebagai sumber data melalui kriteria sampel yang diteliti (Sugiyono, 2001). Adapun kriteria untuk menjadi responden, yaitu: (1). Pengguna social media berdomisili di Semarang yang telah mengetahui akun J.CO Donuts \& Coffee; (2) Berusia 15-45 tahun; (3) Pernah melakukan pembelian di J.CO Donuts \& Coffee Semarang; (4) Bersedia untuk dijadikan responden terkait dengan penelitian pengaruh social media marketing dan brand awareness terhadap minat beli di J.CO Donuts \& Coffee Semarang.

Menurut Cooper dan Emory (1996) dituliskan bahwa formula dasar dalam menentukan ukuran sample untuk populasi yang tidak terdefinisikan secara pasti jumlahnya sample ditentukan secara 
langsung sebesar 100 responden. Peneliti menggunakan sampel langsung, sebanyak 100 dikarenakan jumlah pembeli produk J.CO Donuts \& Coffee di Kota Semarang tidak dapat didefenisikan secara pasti jumlahnya. Untuk itu sampel yang di ambil dari populasi harus benar-benar representative atau mewakili. Dengan perbandingan 60:40 untuk kedua cabang J.CO Donuts \& Coffee di Semarang dengan 60 untuk cabang Paragaon Mall dan 40 untuk cabang Java Mall. Pemilihan perbandingan lebih besar tersebut berdasarkan jumlah penjualan yang lebih banyak sehingga peneliti mendapatkan responden yang lebih banyak berdasarkan perbandingan tersebut.

\section{Hasil dan Pembahasan}

Social Media Marketing memiliki tingkat keeratan hubungan yang lemah terhadap minat beli, yaitu sebesar 0,794 karena terletak pada interval 0,60-0,799. Dilihat dari nilai koefisien determinasi, kontribusi yang diberikan variabel social media marketing terhadap minat beli sebesar 63,1\%. Menurut Siswanto (2013) keberhasilan konsep social media marketing yang dijalankan oleh perusahaan mampu untuk dijadikan media promosi, bahkan media sosial juga digunakan sebagai alat pemasaran yang interaktif, pelayanan, dan membangun hubungan dengan pelanggan dan calon pelanggan). Terdapat pengaruh positif dan signifikan antara social media marketing terhadap minat beli, dilihat dari nilai analisis koefisien regresinya sebesar 0,1436 dan nilai t hitung $(12,392)>t$ tabel $(1,984)$ dengan taraf signifikansi kurang dari 0,05 .

Brand Awareness memiliki tingkat keeratan hubungan yang sedang terhadap keputusan pembelian, yaitu sebesar 0,559, karena terletak pada interval 0,40-0,599. Dilihat dari nilai koefisien determinasi, kontribusi yang diberikan variabel citra merek terhadap keputusan pembelian sebesar 31,3\%. Menurut Aaker dan Keller (1990) semakin tinggi kesadaran merek (brand awareness), kepercayaan merek yang lebih tinggi maka akan mempengaruhi niat beli seseorang. Terdapat pengaruh positif dan signifikan antara brand awareness terhadap minat beli dilihat dari nilai analisis koefisien regresinya sebesar 0,541 dan nilai t hitung $(6,678)>t$ tabel $(1,984)$ dengan taraf signifikansi kurang dari 0,05 .

Minat beli memiliki tingkat keeratan hubungan yang sedang terhadap keputusan pembelian, yaitu sebesar 0,483, karena terletak pada interval 0,40-0,599. Dilihat dari nilai koefisien determinasi, kontribusi yang diberikan variabel minat beli terhadap keputusan pembelian sebesar 23,3\%. Menurut penelitian Pradana (2015) artinya semakin baik perusahaan melakukan pemasaran melalui social media maka akan berpengaruh terhadap minat beli konsumen.

Terdapat pengaruh positif dan signifikan antara harga terhadap keputusan pembelian, dilihat dari nilai analisis koefisien regresinya sebesar 0,469 dan nilai $t$ hitung $(5,454)>t$ tabel $(1,985)$ dengan taraf signifikansi kurang dari 0,05 .

\section{Kesimpulan dan Saran}

Berdasarkan hasil penilaian terhadap 100 responden yang dilakukan mengenai pengaruh social media marketing dan brand awareness terhadap keputusan pembelian melalui minat beli, dapat disimpulkan sebagai berikut: (1) Berdasarkan hasil penelitian diketahui bahwa presepsi responden terhadap variabel Social media marketing pada J.CO Donuts \& Coffee adalah baik, artinya responden menilai bahwa akun social media dari J.CO Donuts \& Coffee layak untuk mereka follow karena memuat pesan yang berkualitas dan foto-foto yang di unggah menarik. Namun masih terdapat indikator yang berada dibawah ratarata yaitu mengenai frekuensi keaktifan social media dalam mengunggah postingan menurut responden belum terlalu aktif dan perlu ditingkatkan; (2) Berdasarkan hasil penelitian diketahui bahwa presepsi responden terhadap variabel Brand Awareness dari J.CO Donuts \& Coffee adalah baik, artinya responden sadar akan keberadaan brand J.CO Donuts \& Coffee sebagai salah satu café retail dengan donat menjadi menu utamanya karena J.CO 
terkenal memiliki produk donat yang berbeda dengan lainnya dengan berbagai macam produk yang ditawarkan responden dapat memahami produk-produk dari J.CO Donuts \& Coffee. Namun masih terdapat indikator yang berada dibawah rata-rata yaitu mengenai presepsi J.CO Donuts \& Coffee menjadi pilihan utama; (3) Berdasarkan hasil penelitian diketahui bahwa persepsi responden terhadap variabel minat beli dari J.CO Donuts \& Coffee adalah tinggi, artinya responden tertarik dengan produk-produk dari J.CO Donuts\& Coffee. Namun untuk indikator yang belum mencapai rata-rata yaitu mengenai keinginan untuk membeli produk dan presepsi memilih produk J.CO Donuts \& Coffee dibanding produk lain itu disebabkan karena harga produk J.CO Donuts \& Coffee cukup mahal; (4) Berdasarkan hasil penelitian diketahui bahwa persepsi responden terhadap keputusan pembelian dari J.CO Donuts \& Coffee dipersepsikan dengan tinggi, hal ini dikarenakan responden mau untuk melakukan pembelian ulang produk J.CO Donuts \& Coffee dan responden akan merekomendasikannya kepada orang terdekatnya. Namun masih ada indikator yang belum mencapai rata-rata yaitu frekuensi untuk membeli produk J.CO Donuts \& Coffee yang tidak terlalu sering karena harga J.CO Donuts \& Coffee menurut mereka lebih mahal; (5) Berdasarkan hasil analisis regresi tahap pertama bahawa variabel social media marketing dan brand awareness menunjukkan terdapat hubungan positif dengan minat beli, maka semakin besar social media marketing dan brand awareness akan meningkatkan minat beli; (6) Berdasarkan hasil analisis regresi dua tahap diketahui bahwa variabel minat beli dapat menjadi variabel intervening dari social media marketing dan brand awareness terhadap keputusan pembelian; (7) Variabel social media marketing (X1) mempunyai pengaruh yang positif dan signifikan terhadap variabel minat beli $(Z)$, yang berarti semakin baik postingan di akun social media dari J.CO Donuts \& Coffee maka semakin tinggi pula minat beli begitu pula sebaliknya; (8) Variabel brand awareness (X2) mempunyai pengaruh yang positif dan signifikan terhadap variabel minat beli (Z), yang berarti semakin baik brand awareness yang dibangun oleh
J.CO Donuts \& Coffee maka semakin tinggi pula minat beli begitu pula sebaliknya; (9) Variabel minat beli mempunyai pengaruh yang positif terhadap variabel keputusan pembelian (Y), yang berarti semakin tinggi minat beli yang dihasilkan di benak konsumen maka semakin tinggi pula tingkat keputusan pembelian.

Berdasarkan kesimpulan yang diperoleh dalam penelitian ini, maka diajukan saransaran sebagai berikut: (1) Pada variabel social media marketing terdapat indikator yang dibawah nilai rata-rata yaitu mengenai frekuensi keaktifan akun social media J.CO Donuts \& Coffee. Saran yang dapat peneliti berikan adalah mengunggah foto di saat waktu prime time. Waktu prime time menurut responden sendiri, mereka sering menggunakan smartphone secara aktif di jam-jam istirahat seperti jam makan siang, atau sepulang aktivitas baik yang bekerja maupun yang bersekolah. Agar lebih efektif dalam menggunakan social media, sebaiknya J.CO Donuts \& Coffee juga menggunakan fitur iklan bersponsor pada Instagram dan facebook agar postingan bisa di jangkau sesuai target baik usia, gender, ataupun hobi. Dengan cara itu akun social media dapat lebih aktif, efektif dan lebih efisien; (2) Pada variabel brand awareness terdapat indikator yang dibawah nilai rata-rata yaitu mengenai presepsi J.CO Donuts \& Coffee menjadi pilihan utama. Saran yang dapat peneliti berikan adalah karena segmentasi J.CO Donuts \& Coffee yang diperuntukkan untuk konsumen kelas menengah ke atas maka J.CO sebaiknya lebih fokus pada apa yang menjadi kebiasaan mereka seperti kedekatan konsumen kelas menengah ke atas dengan berbagai kemudahan dan kecanggihan teknologi. Selama ini J.CO belum mengembangkan aplikasi di smartphone dan hanya menggunakan situs web dan social media dalam memberikan informasi dan pemesanan produk, untuk menunjang kemudahan tersebut akan lebih baik jika J.CO Donuts \& Coffee memiliki aplikasi smartphone untuk bisa di download di smartphone yang berbasis IOS ataupun smartphone berbasis android, karena dengan aplikasi tersebut J.CO dapat lebih mudah untuk sistem penginformasian dan layanan pemesanan lewat aplikasi tersebut dapat 
dikatakan lebih efektif dan lebih efisien sesuai dengan keinginan konsumen pada segmentasi J.CO Donuts \& Coffee yakni konsumen kelas menengah ke atas.

\section{Daftar Referensi}

Abdullah, Thamrin dan Francis Tantri. (2012). Manajemen Pemasaran. Depok: PT. Raja Grafindo Persada.

Afifah, Khansa. (2016). Pengaruh Social Media Marketing Instagram terhadap Tingkat Brand Awareness Roaster and Bear Coffee Lounge \& Kitchen. Jurnal Komunikasi, Universitas Gadjah Mada Yogyakarta. Diakses tanggal 5 Januari 2018 Pukul 19.05 WIB.

AG. Suyono, Sri Sukmawati Pramono. (2012). Pertimbangan dalam Membeli Produk Barang maupun Jasa. Jakarta: Intidaya Press.

Alma, Buchari. (2004). Manajemen Pemasaran dan Pemasaran Jasa. Bandung: Alfabeta.

Amstrong dan Kotler . (2003). Dasar-dasar Pemasaran Jilid I, Edisi kesembilan. Jakarta: PT. Indeks Gramedia.

Cooper, D.R. dan Emory. (1995). Metode Penelitian Bisnis. Jakarta: Erlangga.

Daft, Richard L. (2010). Era Baru Manajemen. Jakarta: Salemba Empat.

Darmadi, Durianto dkk. (2001). Strategi Menaklukan Pasar Melalui Riset Ekuitas dan PerilakuMerek. Jakarta: PT. Gramedia Pustaka Utama.

Kotler, Philip dan Kevin Lane Keller. (2009). Manajemen Pemasaran Jilid I dan II. Jakarta: PT.Gramedia Pstaka Utama.

Margono. (2004). Metodologi Penelitian Pendidikan. Jakarta: Rineka Cipta.
Nursalam. (2008). Konsep dan Penerapan Metodologi Penelitian. Jakarta: Salemba Medika.

Pradana, Thoriq Anugrah Fatra. (2014). Pengaruh Brand Awareness terhadap Minat Beli Konsumen Jasa Reservasi Hotek secara Online pada situs goindonesia.com. Jurnal Manajemen Bisnis Telekomunikasi dan Informatika, Vol. 2, No. 3.

Putri, Citra Sugianto. (2016). Pengaruh Media Sosial terhadap Keputusan Pembelian Konsumen Cherie melalui Minat Beli. Jurnal Manajemen dan Bisnis, Vol. 1, No. 5.

Rahman, Arif. (2010). Strategi DaHXyat Marketing Mix. Jakarta: Trans Media.

Santoso dan Tjiptono. (2001). Riset Pemasaran. Yogyakarta: Andi Offset.

Sekaran. (2003). Manajemen Pemasaran. Bandung: Alfabeta.

Setiawan, Iwan dan Yosanova Savitry. (2016). "New Content Marketing" Gaya Baru Pemasaran Era Digital. Jakarta: Pt.Gramedia Pustaka Utama.

Stanton, William J. (1996). Prinsip Pemasaran. Jakarta: Erlangga.

Sugiyono. (2007). Metodologi Penelitian Bisnis. Bandung: Alfabeta.

Sutisna. (2003). Perilaku Konsumen dan Komunikasi Pemasaran. Bandung: PT. Remaja Rosdakarya.

Swastha, Basu dan Irawan. (2003). Manajemen Pemasaran Modern. Yogyakarta: Liberty.

Tjiptono, Fandy. (2007). Starategi Pemasaran, Edisi kedua. Yogyakarta: Andy.

Zanjabilla, Ridwan dan Rahmat Hidayat. (2017). Analisis Pengaruh Social Media 
Marketing terhadap Keputusan

Pembelian Bandung Techno Park (Studi pada Pelanggan Bandung Techno Park 2017. Jurnal Manajemen Pemasaran. Diakses tanggal 6 Januari 2018 Pukul 06.19 WIB

Web:

www.jcoindonesia .com www.topbarand-award.com/kategoricafekopi

www.instagram.com/jcoindonesia

www.facebook.com/iamjcolovers

www.twitter.com/jcoindonesia

www.youtube.com/jcoindonesia 